Article

\title{
Measuring Improvement of Economic Condition in State-Owned Forest Farms' in China
}

\author{
Rongyuan Chen, Wenhui Chen *, Mingxing $\mathrm{Hu}^{*}$ and Wei Huang \\ School of Economics and Management, Beijing Forestry University, Beijing 100083, China; \\ chenrongyuan1990@163.com (R.C.); huangwei9613@163.com (W.H.) \\ * Correspondence: chenwenhui77@163.com (W.C.); hmx5416@126.com (M.H.)
}

Received: 12 December 2019; Accepted: 19 February 2020; Published: 20 February 2020

\begin{abstract}
An important policy cornerstone for China to reduce poverty includes China's goal of achieving complete poverty alleviation in its state-owned forest farms by 2020. This study describes and documents the poverty reduction effect in impoverished Chinese state-owned forest farms. Based on a sample of 4855 state-owned forest farms in 31 provinces in China from 2008 to 2017, this paper uses the difference-in-difference method to study the dynamic process of poverty reduction by policies for impoverished state-owned forest farms. The results show that the implementation of the policy significantly promoted the economic development of impoverished state-owned forest farms and caused the treatment group to increase by approximately $10.6 \%$ over the control group. Moreover, the establishment of a list of impoverished state-owned forest farms had an indirect impact on the economic performance of forest farms, through channels such as infrastructure poverty alleviation, human capital investment, and per capita income of forest farm employees. Additionally, the effects of the policy on non-impoverished counties were stronger than that on impoverished counties, and impoverished state-owned forest farms may not appear in impoverished counties. The degree of financial dependence of the local government had a significant positive impact on the economic development of impoverished state-owned forest farms. The effects of the policy on different forest farms were heterogeneous. Our study provides recommendations for the future development of impoverished Chinese state-owned forest farms and for the improvement of poverty alleviation efficiency.
\end{abstract}

Keywords: state-owned forest farms; economic development; poverty reduction effect; difference-indifference method

\section{Introduction}

Due to the continuous growth of the global population and the increase in demand for food and land, there has been unprecedented interest in sustainable forest management (SFM). It is worth noting that developing countries still have a strong dependence on natural resources, and the amount of wood harvested has slightly increased [1]. In 2017, the Inter-Agency Expert Group on Sustainable Development Goals (IAEG-SDG) proposed progress goals of studying forests and sustainable forest management, as well as protecting mountain ecosystems [2]. The improvement of forest conditions plays an important role in slowing forest degradation and deforestation, accelerating forest growth and regeneration, and improving the functions of ecological services and farmers' livelihoods (including reducing poverty, increasing income, and expanding employment) [3-5].

According to the statistics, China's forest area ranks fifth in the world, with a total of 220 million hectares, accounting for $5 \%$ of the global forest area. Simultaneously, it is also the country with the largest annual net growth in forest area, an average annual increase of 1.542 million hectares and the forest coverage rate reached $22.9 \%$ [6]. In 2017, the Chinese government proposed a strategy for rural 
revitalization, affirming the immense ecological and economic values of state-owned forest farms $[7,8]$. State-owned forest farms are owned by the state. The main task is to restore, cultivate, and maintain the health and integrity of forest ecosystems. Meanwhile, the purpose is to provide forestry products and ecological services to the society with productive institutions and economic organizations. As of 2018, the number of Chinese state-owned forest farms had reached 4855, which were distributed throughout 31 provinces (cities, counties) of China with a total scale of operations of 64.53 million hectares [9]. In the "Strategic Plan for Rural Rejuvenation (2018-2022)" issued in 2019, it was pointed out that the ecological benefits of state-owned forest farms must be taken into account [8]. In 2013, the State Forestry and Grassland Administration of China promulgated the industry standard "Defined Indicators and Methods for State-owned Poor Forest Farms" (LY/T2088-2013), thereby defining the list of impoverished state-owned forest farms, among which the number of state-owned impoverished forest farms was 3455 , accounting for $71 \%$ of all Chinese state-owned forest farms [9-11]. The state-owned impoverished forest farm refers to a state-owned forest farm with a loss or small profit and poor production and living facilities. The main task is to cultivate and protect ecological public welfare forests [3-5].

Poverty measurement issues in areas rich in natural resources have been extensively studied, both theoretically and empirically. Both theoretical and empirical studies have shown that areas rich in forest resources are more prone to poverty. Earlier analysis of poverty in areas rich in forest resources mainly included "rent-seeking theories", "institutional theories", and "Dutch disease effects" proposed in the theory [12-16]. From the 1990s, the focus of scholars, both at home and abroad, has shifted from theoretical analysis to empirical research, where poverty has been measured using the Multidimensional Index System (MPI) of forest resource poverty [17-19]. The abundance of resources reduced the economic growth rate through the role of the transmission mechanism, which has a crowding-out effect on economic development, thus leading to local poverty $[13,20,21]$. In addition, over-reliance on resources can also affect the revenue of the resource sector [22]. Resource endowment has an important influence on the developmental path and quality of the system, which then affects the national economic performance [23]. Meanwhile governmental actions play an important role [24-26]. Government rent-seeking behavior will reduce the effective marginal output of capital and the balance of capital stock, inevitably leading to the generation of corrupt and predatory governments, thereby exacerbating the regional economic downturn [27-29]. In terms of research into impoverished state-owned forest farms should be defined from a multidimensional perspective of poverty in China [30,31]. Employees of state-owned forest farms life satisfaction, employee acquisition, and human capital incentive and restraint mechanisms are key to achieving sustainable management of state-owned forest farms $[17,32,33]$. Besides, the root cause of poverty in state-owned forest farms is the concept of resource-based management [34,35]. Moreover, the workers of state-owned forest farms are considered to be overly dependent on government subsidies or operating incomes [36-39].

Thus, most of the theoretical and empirical studies in the current research have mainly analyzed the economic development of resource-rich regions, but there have been few studies on how forest resource support policies can reduce regional poverty. In addition, the current research has mainly been aimed at studies limited to the development of impoverished state-owned forest farms, which have all found that governmental actions have a significant impact on the poverty reduction measures of state-owned forest farms. However, the establishment of a list of impoverished state-owned forest farms is an important poverty reduction policy in China. The means, mechanisms, and effects of this policy may be similar to other poverty reduction policies but are not exactly the same.

This paper's purpose is to seek objective evaluation and full verification of the correlation between the improvement of the economic performance of impoverished state-owned forest farms and the establishment of these lists' requirements. To what extent does the improvement of economic performance and poverty alleviation follow from the establishment of a list of impoverished state-owned forest farms? Is there heterogeneity in the policy effects of different state-owned impoverished forest farms? Is it possible to achieve sustainable self-development of impoverished forest farms, to eliminate poverty, and to reduce the gap between forest farms? 
The contributions of this paper are reflected in the following aspects. First, we present the first attempt to examine the policy effects and transmission mechanisms of the establishment of a list of impoverished state-owned forest farms from the perspective of China, based on China's national forestry from 2008 to 2017. The Bureau's survey data on state-owned forest farms in 31 provinces (municipalities and autonomous regions) in China used long-term tracking samples to identify policy effects through the use of the difference-in-difference (DID) method, providing empirical evidence for the further improvement and future development of poverty reduction in impoverished state-owned forest farms. Second, the gradual advancement method is used to empirically test the differences between the impoverished counties and the degree of financial dependence, deepening the understanding of the economic growth effects caused by the policy. Third, an in-depth discussion of the impact of the policy on the poverty reduction measures of forest farm staff income, poverty alleviation by infrastructure construction, and human capital poverty alleviation is provided. Furthermore, we provide effective policy recommendations for further improving poverty reduction strategies and achieving poverty reduction goals. Finally, empirical evidence of the effects of poverty reduction policies in developing countries is provided.

\section{Materials and Methods}

\subsection{Research Hypothesis}

State-owned forest farm poverty is characterized by industrial poverty, obvious intergenerational transmission of employee poverty, and poor self-poverty alleviation capabilities. From the perspective of industrial poverty, forestry is one of the national poverty industries, with its development lagging far behind that of other industries. According to the national economic industry group, the average wage of employees engaged in agriculture, forestry, animal husbandry, and fishery is only half the average level of various industries in which the per capita wage is low. In addition, state-owned forest farms are a vulnerable group in the forestry industry, and the average annual salary of employees in impoverished state-owned forest farms often makes it more difficult to maintain their daily livelihoods. State-owned forest farms are an ecological public welfare undertaking: Expenditure is generally not guaranteed, and the legitimate interests of employees are not protected. From the perspective of the distribution of impoverished state-owned forest farms, the distribution of China's impoverished state-owned forest farms presents agglomeration and some general characteristics, mainly being concentrated in the central and western regions, with some heterogeneity in regional development.

Moreover, the intergenerational transmission of employee poverty is obvious. First, due to geographical constraints and economic constraints-especially the serious shortage of education resources - the intergenerational transmission of poverty among state-owned forest farm workers is obvious. Second, the employees of state-owned forest farms are protecting the ecological aspects of society, their rate for labor time is low, and their children are continuously poverty.

Finally, self-poverty is common. First, they are highly dependent on forest resources. Impoverished state-owned forest farms rely mainly on forest resources to develop ecological benefits, where the economic benefits are weak. Second, the poor conditions of forest farms are evident, the average age of employees in professional and technical positions has reached 50 years, and young people are reluctant to work on forest farms. With the aging of the workforce, the quality and the technical abilities of the staff decrease, and the forest farm's self-development and self-poverty abilities are getting lower and lower.

The poverty reduction policy for impoverished state-owned forest farms has been defined by the state, according to industry standards. The state and superior government can provide policy support, such as financial transfer payments and special poverty alleviation funds, which can be used to improve the treatment of employees in impoverished state-owned forest farms, improve the road and transportation infrastructure, and increase capital accumulation in forest farms. At the same time, the poverty alleviation policy of impoverished state-owned forest farms can improve the local economic and social development through the improvement of the external policy environment. However, the 
implementation of policy measures has a certain lag. The longer the policy is implemented, the more it can continue to improve poverty alleviation or stabilize poverty in impoverished state-owned forest farms. Based on this, this article proposes the following research hypotheses:

Hypothesis 1 (H1). The poverty reduction policies for impoverished state-owned forest farms can effectively improve the economic situation of impoverished state-owned forest farms.

Hypothesis 2 (H2). Due to differences in economic foundations, factor endowment structures, and geographical and administrative characteristics, the policy effects for different forest farms are heterogeneous.

\subsection{Setting Model}

Although the single-difference method can be used to directly compare the policy effects on impoverished state-owned forest farms before and after the poverty reduction policy, based on an examination of the impact of poverty-reduction policies on impoverished state-owned forest farms for reducing poverty vulnerability, the poverty-reduction policies for impoverished state-owned forest farms were not random. Therefore, the "quasi-natural experiment" of the poverty reduction policy for impoverished state-owned forest farms should be used, and the double-difference method [40,41] should be used to estimate the effect of poverty reduction policies on impoverished state-owned forest farms.

To verify research hypothesis 1 , the following model was constructed in order to test the net effect of poverty reduction policies on poverty vulnerability in impoverished state-owned forest farms:

$$
Y_{i t}=\beta_{0}+\beta_{1} \cdot \text { Treat } \cdot T+\sum \beta_{X} \cdot X++\delta_{i}+\gamma_{t}+\varepsilon_{i t} .
$$

In the Equation (1), $Y_{i t}$ is the logarithmic value of the annual income of the state-owned forest farm, which is the explanatory variable used to measure the degree of poverty. The subscripts $i$ and $t$ indicate the $i$-th forest farm and the $t$-th year, respectively. Treat is used to discriminate between the experimental group and control group, and $T$ is used to distinguish between before and after the experiment. The interaction term Treat $\times T$ is a core explanatory variable that measures whether the poverty reduction policy was implemented to establish a state-owned poverty forest farm. During the sample period, if the $i$-th forest farm was set up as an impoverished state forest farm, Treat $\times T=1$, otherwise, it was $0 . X$ indicates the control variables, including employee income, forest farm income, and expenditure status, forest resource base, human resource base, infrastructure, and production conditions, $\delta_{i}$ is the provincial fixed effect, which controls the individual fixed effects that do not change over time and affect the state-owned forest farm income, $\gamma_{t}$ represents the period effect, which does not affect all provinces over time, and $\varepsilon_{i t}$ represents a random interference term. In order to address potential sequence correlation and heteroscedasticity issues, this paper reports robust standard error clustering with forest farms. The estimated coefficient $\beta_{1}$ is the policy effect of interest in this paper. If the policy is effective, $\beta_{1}$ is significantly positive.

In order to verify research hypothesis 2 and to test whether there were heterogeneous differences in this policy, this article further expands on the basis of Equation (1) and builds the model as follows:

$$
\begin{gathered}
Y_{i t}=\beta_{0}+\beta_{1} \cdot \text { Treat } \cdot T \cdot \text { povcou }+\beta_{2} \cdot \text { Treat } \cdot T+\beta_{3} \cdot \text { povcou }+\sum \beta_{X} \cdot X+\delta_{i}+\gamma_{t}+\varepsilon_{i t}, \\
Y_{i t}=\beta_{0}+\beta_{1} \cdot \text { Treat } \cdot T \cdot \text { fin expen }+\beta_{2} \cdot \text { Treat } \cdot T+\beta_{3} \cdot \text { fin exp ense }+\sum \beta_{X} \cdot X++\delta_{i}+\gamma_{t}+\varepsilon_{i t} \cdot
\end{gathered}
$$

In Equation (2), povcou is a dummy variable for impoverished counties. If the $i$-th forest farm was located in a poor county, povcou $=1$, otherwise, it is 0 . Equation (2) mainly describes whether there was a difference in the policy effect between impoverished counties and non-impoverished counties. Furthermore, finexpen in Equation (3) is the proportion of a forest farm's financial input relative to its total income, which measures its degree of financial dependence. The larger the value, the greater the 
state-owned forest farm's financial dependence on the higher government. Equation (3) mainly examines whether the effect of the policy was affected by the degree of government financial dependence.

\subsection{Data Sources}

The data used were sourced from the mixed cross-section data of the National Forestry and Grassland Bureau's state-owned forest farm management and reform investigation team from 2008 to 2017, covering a total of 4855 state-owned forest farms in 31 provinces (cities, districts). The questionnaire contained seven levels of information about the basic conditions of the forest farm, infrastructure, forest resources, ecological and cultural conditions, forest management, industrial development, and financial management.

\subsection{Variable Selection}

The variables used in this article and their definitions are as follows:

(1) The explained variable: $Y_{i t}$ is the explanatory variable. In this paper, the logarithmic value (Inyield) of the income of each state-owned forest farm was selected to explain the poverty level of the state-owned forest farm.

(2) Core explanatory variables: The interaction term Treat $\times T$ of the impoverished state-owned forest farm. According to the "LY/T 2088-2013 State-owned Poor Forestry Farm's Defining Indicators and Methods" issued by the State Forestry Administration, 3455 state-owned forest farms in 31 provinces nationwide were defined as impoverished state-owned forest farms. $T$ is a dummy variable in the experimental period, and the coefficient estimate of the interaction term Treat $\times T, \beta_{1}$, is a double difference estimator, indicating that the poverty reduction policy of the state-owned impoverished forest farm reduced the net impact of its poverty vulnerability if and only if the $i$-th state-owned forest farm in 2013 was a newly transferred state-owned impoverished forest farm, that is, when $t \geq 2013$, Treat $\times T$ is assigned a value of 1 and vice versa. This article uses the proportion of government institution input costs and forest farm income (finexpen) to measure the financial dependence of government forest farms while using the proportion of higher government investment to total forest farm income to characterize the degree of government intervention in the economy (govexpen).

(3) Control variables: In addition to the establishment of the impoverished state-owned forest farm list, there are many other factors that will affect the economic development performance of an impoverished state-owned forest farm. Therefore, it was necessary to control the interference of these exogenous factors. The ratio of number of employees and staff employed in state-owned forest farms was used to reflect the impact of human capital on the level of economic development of the forest farm. The proportion of ecological public welfare forests (welfor) was selected to reflect the status of forest resources and resource utilization potential. The ratio of available forest area (use) was selected to reflect the potential of forest land resources for forest farms to conduct business activities, which is an important basis for the future development of forest farms, and the number of kilometers from the county seat (couroad) was selected to measure the degree of distance of the forest farms from the outside world.

(4) Other variables: The average income of the employees (income) and expenditure status of the forest farm (pay) were selected to reflect the effect of the government's direct commercialized wage management policy and the actual level of livelihood of the employees. At the same time, the road, power connection electric, internet, and water conditions of the forest farm and forest area were selected to reflect the construction of basic facilities of the forest farm. In addition, the ratio of off-site office buildings to office buildings (offic) was selected to reflect the working environment of the employees on the forest farm and to analyze its positive impact on the work of the employees. The proportion of the number of employees with junior college education or above relative to the total number of employees $(e d u)$ was selected to reflect the professional level of the forest farm employees. 
As can be seen from Table 1, in terms of economic conditions, the average annual income of employees in state-owned forest farms, for the total number of employees in forest farms, was only 0.78 , indicating that the actual level of livelihood of the sampled state-owned forest farms was low. Forest farm personnel expenditure accounted for $40.53 \%$ of the average proportion of the total income of the forest farm, indicating that personnel costs accounted for a higher proportion of the total expenditure of the forest farm. However, local government investment and fiscal transfer payment capabilities were low. From the perspective of the improvement of forest resources and infrastructure, the sampled forest farms had a relatively high proportion of potential resources, channels, and calls for operating activities and backup forest land resources, indicating that the sample forest farms had higher ecological value and the infrastructure was gradually improved. From the perspective of the development capacity, the sampled forest farms had a higher asset-liability ratio and lower total assets, indicating that the sample forest farm still had to work to promote higher capital formation.

Table 1. Definition of main variables and their descriptive statistics.

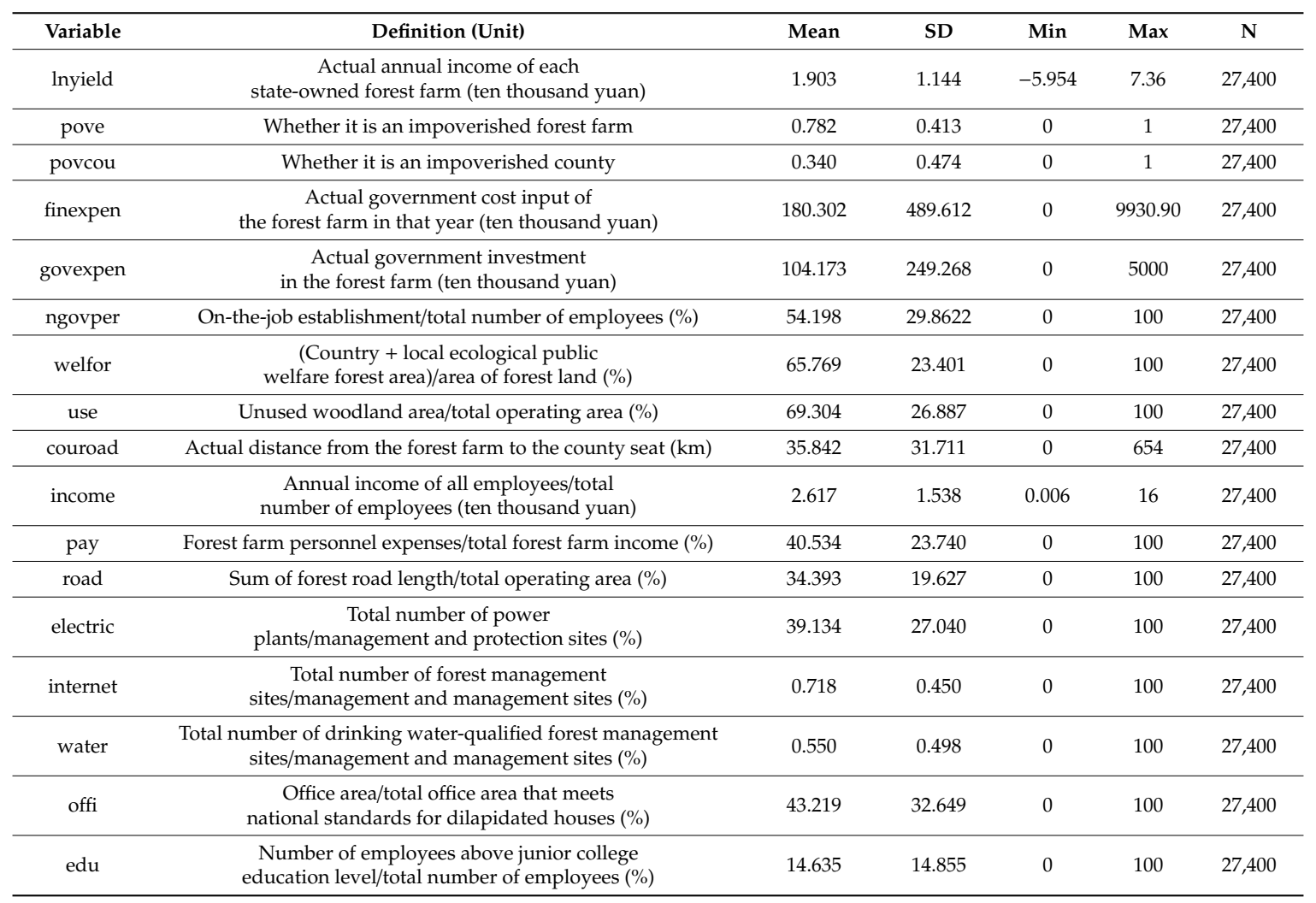

\section{Results}

The main empirical results of the policy evaluation of the establishment of impoverished state-owned forest farms are divided into three parts: First, using the Difference-in-Difference (DID)method to estimate the impact of the establishment of impoverished state-owned forest farms on the economic development level of state-owned forest farms. Second, a recognition hypothesis test and a robustness test are performed to eliminate estimation bias caused by missing variables. Third, the heterogeneity of policy effects and spillover effects are discussed.

\subsection{The Analysis of Benchmark Regression Results}

According to model (1), the logarithmic value of the state-owned forest farms, lnyield, was used as the explanatory variable in order to estimate the average effect of the poverty reduction policy of listing the impoverished state-owned forest farms on reducing the vulnerability of the impoverished forest farms to validate the first research hypothesis. In Table 2, column (1) is the regression result without 
the control variable and column (2) is the control result with the control variable. However, there was no control period effect or individual effect, including only pove and year, along with the interaction terms. In column (3), the individual effects and period effects were controlled at the provincial level.

Table 2. Regression results.

\begin{tabular}{cccc}
\hline Variable & $\mathbf{( 1 )}$ & $\mathbf{( 2 )}$ & $\mathbf{( 3 )}$ \\
\hline DID & $0.1517^{* * *}$ & $0.0555^{* * *}$ & $0.1064^{* * *}$ \\
year & $(0.0262)$ & $(0.0173)$ & $(0.0289)$ \\
& $0.0297^{* * *}$ & $0.0286^{* * *}$ & $(0.0080)$ \\
\hline pove & $(0.1068)$ & $0.1964^{* *}$ & \\
\hline control & $0.1916^{* *}$ & $(0.0734)$ & YES \\
\hline constant & $(0.0746)$ & YES & $1.8570 * * *$ \\
\hline Individual effect & NO & $1.9761^{* * *}$ & YES \\
Time effect & $2.0343^{* * *}$ & $(0.1087)$ & YES \\
\hline$R^{2}$ & $(0.1083)$ & & 0.0821 \\
\hline$N$ & 0.0034 & 0.0040 & 26356 \\
\hline
\end{tabular}

Note: ${ }^{*}, * *$, and ${ }^{* * *}$ represent the significance levels of $10 \%, 5 \%$, and $1 \%$, respectively. DID: Difference-In-Difference.

It can be seen that, regardless of whether the control variable was added, when using lnyield as the explanatory variable, the coefficient of the crossover term Treat $\times T$ was significantly positive, and from the size of the coefficient in column (1), there was no control over other effects. In the development of state-owned forest farms, the income after the impact of the poverty reduction policy of establishing the list of impoverished state-owned forest farms was about $5 \%$ different from that of the control group. The result in column (2) is consistent with the result in column (1), where the estimated coefficient was about $5 \%$.

In terms of the coefficients in column (3), after controlling the factors that affected the state of forest resources and infrastructure, the influence of the poverty reduction policy of establishing the list of impoverished state-owned forest farms on the income of impoverished state-owned forest farms was significant, with an increase of about $10.6 \%$. The coefficient estimates in columns (1) and (2) do not control for individual effects and period effects and, thus, estimation errors were difficult to avoid for the policy effects due to individual heterogeneity. After adding the control variable, the estimated value of the coefficient in column (3) was about $10.6 \%$. This result is consistent with the empirical results of a series of robustness test sections (presented later) and, thus, the results are credible. The benchmark regression results show that the establishment of the list of impoverished state-owned forest farms had a significantly positive impact on the economic development of impoverished state-owned forest farms. In the above regressions, the standard errors were clustered to the provincial level [37-39].

\subsection{Robustness Test}

According to the research above, the establishment of the list of impoverished state-owned forest farms did not reduce the economic performance between the forest farms, but this conclusion may have been affected by the omitted variables. In order to verify the reliability of the DID identification strategy in this paper, the following identification tests were performed:

\subsubsection{Eliminating the Impact of Impoverished Counties}

In the sample of this article, both the treatment group and the control group had impoverished state-owned forest farms located in impoverished counties. In order to determine whether the sample 
affected the development of the forest farm economy due to the impoverished counties, the state-owned forest farms located in impoverished counties are listed in column (1) of Table 3. The samples were then removed, and the DID method was used to evaluate the effect of policies set up by impoverished state-owned forest farms. It can be seen that, compared with the benchmark regression above, after excluding impoverished counties, the estimated negative value of the coefficient of poverty reduction policy for the establishment of the list of impoverished state-owned forest farms increased significantly, which was verified by the conclusions of the heterogeneity analysis (Table 3).

Table 3. Robustness test analysis.

\begin{tabular}{|c|c|c|c|c|c|}
\hline & (1) & (2) & (3) & (4) & (5) \\
\hline DID & $0.1352 * * *$ & $0.0564 *$ & $0.1064^{* * *}$ & $0.1026^{* * *}$ & $0.1083^{* * *}$ \\
\hline \multirow[t]{2}{*}{ ngovper } & 0.0003 & $0.0006^{* *}$ & 0.0006 & 0.0006 & 0.0057 \\
\hline & $(0.0005)$ & $(0.0003)$ & $(0.0005)$ & $(0.0005)$ & $(0.0049)$ \\
\hline welfor & 0.0011 & $0.0013^{* * *}$ & $0.0013^{* *}$ & $0.0013^{* *}$ & $0.0013 * *$ \\
\hline use & $(0.0009)$ & $(0.0003)$ & $(0.0008)$ & $(0.0008)$ & $(0.0008)$ \\
\hline \multirow[t]{2}{*}{ couroad } & $0.0006^{*}$ & 0.0002 & 0.0002 & 0.0002 & 0.0018 \\
\hline & $(0.0003)$ & $(0.0002)$ & $(0.0003)$ & $(0.0003)$ & $(0.0003)$ \\
\hline L.control & & YES & & & \\
\hline Individual effect & YES & YES & YES & YES & YES \\
\hline$N$ & 17,242 & 26,356 & 26,356 & 26,356 & 26,356 \\
\hline
\end{tabular}

Note: ${ }^{*}, * *$ and ${ }^{* * *}$ represent the significance levels $10 \%, 5 \%$, and $1 \%$, respectively. OLS: The least square method.

\subsubsection{Control Variable Lags by One Period}

In order to avoid potential endogenous problems due to the adverse effects of the selected variables and the establishment of the list of impoverished state-owned forest farms, all control variables were lagged by one period and re-regressed, as shown in column (2) of Table 3. The signs and significance of the coefficients were basically consistent with the benchmark regression results, but the estimated coefficients all declined due to the lag of the control variable. Thus, the robustness of the conclusion of this paper was verified again.

\subsubsection{Radius Matching, Kernel Matching, and Nearest-Neighbor Matching}

In order to ensure the robustness of the above regression results, we further used the DID method and the least square method (OLS) to analyze the policy effects of the establishment of the list of impoverished state-owned forest farms. The nearest-neighbor matching, radius matching, and kernel matching methods were used by setting up samples (treatment groups) of impoverished state-owned forest farms to match the control group, such that the experimental group and control group had no significant effect before setting up the list of impoverished state-owned forest farms, in order to reduce endogeneity problems caused by self-selection bias in impoverished state-owned forest farms [40,41]. Columns (3), (4), and (5) are the estimation results of radius matching, kernel matching, and nearest-neighbor matching, respectively. From the estimation results of the three matching methods in Table 3, it can be seen that the estimation coefficients, symbols, and significance levels of the different matching methods were basically consistent with the benchmark regression results. Therefore, the establishment of the impoverished state-owned forest farm list considered in this paper had a significant impact on the economic development of the forest farms, where the positive effects were robust. 


\subsection{Analysis of the Impact Mechanism}

In order to investigate whether the policy indirectly promoted the economic performance of impoverished state-owned forest farms through corresponding poverty alleviation measures, an intermediary effect test method was adopted. Based on the identification of the first policy effect, the following test equations were constructed:

$$
\begin{gathered}
Y_{i t}=\beta_{0}+\beta_{1} \cdot \text { Treat } \cdot T+\sum \beta_{X} \cdot X++\delta_{i}+\gamma_{t}+\varepsilon_{i t}, \\
M_{i t}=\alpha_{0}+\alpha_{1} \cdot \text { Treat } \cdot T+\sum \alpha_{X} \cdot X++\delta_{i}+\gamma_{t}+\varepsilon_{i t}, \\
Y_{i t}=\lambda_{0}+\lambda_{1} \text { Treat } T+\lambda_{2} M_{i t}+\sum \lambda_{X} X++\delta_{i}+\gamma_{t}+\varepsilon_{i t},
\end{gathered}
$$

where $\mathrm{M}$ is an intermediary variable, which represents the per capita income of employees (income), infrastructure poverty alleviation (electric, internet, water), and human capital (edu) poverty alleviation. The total effect of policy implementation is $\beta_{1}$. The direct effect is $\lambda_{1}$, and the indirect effect is $\alpha_{1} \lambda_{1}$. According to the test steps of the mediation effect model, $\beta_{1}$ is significantly positive if $\lambda_{1}$ and $\lambda_{2}$ are significantly positive in the regression and the coefficient of $\lambda_{1}$ decreases. This means that $\mathrm{M}$ is a partial

\begin{tabular}{|c|c|c|c|c|c|c|}
\hline & (1) & (2) & (3) & (4) & (5) & (6) \\
\hline DID & $\begin{array}{c}0.1064^{* * *} \\
(0.0211)\end{array}$ & $\begin{array}{c}0.0900 * * * \\
(0.0214)\end{array}$ & $\begin{array}{c}0.1060^{* * *} \\
(0.0211)\end{array}$ & $\begin{array}{c}0.1229 * * * \\
(0.0208)\end{array}$ & $\begin{array}{c}0.1299 * * * \\
(0.0211)\end{array}$ & $\begin{array}{c}0.1055^{* * *} \\
(0.0211)\end{array}$ \\
\hline ngovper & $\begin{array}{c}0.0006 * * \\
(0.0003)\end{array}$ & $\begin{array}{l}0.0005^{*} \\
(0.0003)\end{array}$ & $\begin{array}{c}0.0006^{* *} \\
(0.0003)\end{array}$ & $\begin{array}{c}0.0004 \\
(0.0003)\end{array}$ & $\begin{array}{c}0.0004 \\
(0.0003)\end{array}$ & $\begin{array}{l}0.0005^{*} \\
(0.0003)\end{array}$ \\
\hline welfor & $\begin{array}{c}0.0013^{* * *} \\
(0.0004)\end{array}$ & $\begin{array}{c}0.0011^{* * *} \\
(0.0004)\end{array}$ & $\begin{array}{c}0.0013^{* * *} \\
(0.0004)\end{array}$ & $\begin{array}{c}0.0015^{* * *} \\
(0.0004)\end{array}$ & $\begin{array}{c}0.0013^{* * *} \\
(0.0004)\end{array}$ & $\begin{array}{c}0.0013^{* * *} \\
(0.0004)\end{array}$ \\
\hline use & $\begin{array}{c}-0.0013^{* * *} \\
(0.0003)\end{array}$ & $\begin{array}{c}-0.0013^{* * *} \\
(0.0003)\end{array}$ & $\begin{array}{c}-0.0013 \text { *** } \\
(0.0003)\end{array}$ & $\begin{array}{c}-0.0008^{* *} \\
(0.0003)\end{array}$ & $\begin{array}{c}-0.0011 \text { *** } \\
(0.0003)\end{array}$ & $\begin{array}{c}-0.0013 * * * \\
(0.0003)\end{array}$ \\
\hline couroad & $\begin{array}{c}0.0012^{* * *} \\
(0.0002)\end{array}$ & $\begin{array}{c}0.0012 \\
(0.0002)\end{array}$ & $\begin{array}{c}0.0012 \\
(0.0002)\end{array}$ & $\begin{array}{l}-0.0001 \\
(0.0002)\end{array}$ & $\begin{array}{c}0.0000 \\
(0.0002)\end{array}$ & $\begin{array}{c}0.0002 \\
(0.0002)\end{array}$ \\
\hline income & & $\begin{array}{c}0.0587^{* * * *} \\
(0.0041)\end{array}$ & & & & \\
\hline electric & & & $\begin{array}{c}0.0002 \\
(0.0002)\end{array}$ & & & \\
\hline internet & & & & $\begin{array}{c}0.3891 * * * \\
(0.0209)\end{array}$ & & \\
\hline water & & & & & $\begin{array}{c}0.2647^{* * *} \\
(0.0144)\end{array}$ & \\
\hline edu & & & & & & $\begin{array}{c}0.0172 * * * \\
(0.0040)\end{array}$ \\
\hline constant & $\begin{array}{c}1.8570 * * * \\
(0.0365)\end{array}$ & $\begin{array}{c}1.7623^{* * *} \\
(0.0359)\end{array}$ & $\begin{array}{c}1.8648^{* * *} \\
(0.0372)\end{array}$ & $\begin{array}{c}2.0630^{* * *} \\
(0.0395)\end{array}$ & $\begin{array}{c}1.9741 * * * \\
(0.0376)\end{array}$ & $\begin{array}{c}1.8437^{* * *} \\
(0.0378)\end{array}$ \\
\hline$R^{2}$ & 0.0821 & 0.0859 & 0.0822 & 0.1030 & 0.0944 & 0.0822 \\
\hline$N$ & 26,356 & 26,356 & 26,356 & 26,356 & 26,356 & 26,356 \\
\hline
\end{tabular}
mediation variable. If $\lambda_{1}$ is not significant and $\lambda_{2}$ is significant, then $\mathrm{M}$ is a complete mediation variable.

Table 4. Tests of the mediating effects which affect economic performance.

Note: ${ }^{* * *}$ represents $1 \%$ significance, ${ }^{* *}$ represents $5 \%$ significance, and * represents $10 \%$ significance.

Regression was carried out based on Equations (4) and (5). As shown in Table 4, we used the variables poverty, income, electric, internet, water, and edu in Table 4 as intermediary variables to test the mediation effect. The result of the benchmark regression in column (1) shows that the policy had an effect of $10.6 \%$. After adding the intermediary variables, columns (2), (3), and (6) were significantly positive and 1, respectively, with a decrease in coefficients. For the coefficients in columns (4) and (5), $\lambda_{1}$ was significantly positive, and the $\lambda_{2}$ coefficients increased significantly. The estimation results in columns (2)-(6) show that the selected mediation variables were all mediations and that they all met the theoretical expectations. Thus, the establishment of the list of impoverished state-owned forest farms not only directly promoted the development of the forest farm economy but also indirectly 
promoted the improvement of the economic performance of forest farms through a series of poverty alleviation measures, such as per capita income of employees, poverty alleviation by infrastructure, and talent input.

\subsection{Heterogeneity Analysis}

Due to the heterogeneity of the economic foundations, factor endowment structures, and state-owned forest farm's geographical environments, different forest farms have different policy effects. Therefore, a heterogeneity analysis based on the above regression results was considered to be essential. This article will examine heterogeneity from the following two angles: 1) Whether a forest farm was located in an impoverished county and 2) whether the effect of the policy was affected by the degree of county-level government financial dependence. In Table 3, the regression results in column (1) show the comparison between impoverished state-owned forest farms and impoverished counties. Impoverished state-owned forest farms located in impoverished counties had a significantly positive impact on the economic development of impoverished forest farms, with a policy effect of about $7.7 \%$. The possible reasons for this are (1) China has a series of policy tilts, such as financial support and tax incentives, for impoverished counties. 3) The ownership of impoverished forest farms does not necessarily appear in impoverished counties. The main causes of poverty in impoverished counties were the poor ecological environment and natural endowment, as well as state-owned poverty. In addition, the cause of poverty forest farms is the irrational use of resources. The irrational use of resources will also lead to the emergence of impoverished state-owned forest farms in non-impoverished counties.

Table 5. Heterogeneity analysis results.

\begin{tabular}{|c|c|c|c|}
\hline & (1) & (2) & (3) \\
\hline DID & $\begin{array}{c}-0.1264^{* * *} \\
(0.0355)\end{array}$ & $\begin{array}{c}0.0797^{* * *} \\
(0.0228)\end{array}$ & $\begin{array}{c}0.0680 * * * \\
(0.0223)\end{array}$ \\
\hline DID * povcou & $\begin{array}{c}0.0494 * * * \\
(0.0120)\end{array}$ & & \\
\hline ngovper & $\begin{array}{c}0.0006 \\
(0.0005)\end{array}$ & $\begin{array}{l}0.0006^{* *} \\
(0.0003)\end{array}$ & $\begin{array}{l}0.0006^{* *} \\
(0.0003)\end{array}$ \\
\hline welfor & $\begin{array}{l}0.0013^{* *} \\
(0.0005)\end{array}$ & $\begin{array}{c}0.0012 * * * \\
(0.0004)\end{array}$ & $\begin{array}{c}0.0012 * * * \\
(0.0004)\end{array}$ \\
\hline use & $\begin{array}{c}-0.0013^{* * *} \\
(0.0003)\end{array}$ & $\begin{array}{c}-0.0013^{* * *} \\
(0.0003)\end{array}$ & $\begin{array}{c}-0.0013^{* * *} \\
(0.0003)\end{array}$ \\
\hline couroad & $\begin{array}{c}0.0012 * * * \\
(0.0003)\end{array}$ & $\begin{array}{c}0.0001 \\
(0.0002)\end{array}$ & $\begin{array}{c}0.0002 \\
(0.0002)\end{array}$ \\
\hline govexpen & & $\begin{array}{c}0.0003^{* * *} \\
(0.0000)\end{array}$ & \\
\hline DID * govexpen & & $\begin{array}{l}0.0001 * \\
(0.0000)\end{array}$ & \\
\hline finaexpen & & & $\begin{array}{c}0.0002 * * * \\
(0.0000)\end{array}$ \\
\hline DID* finaexpen & & & $\begin{array}{c}0.0004^{* * *} \\
(0.0001)\end{array}$ \\
\hline constant & $\begin{array}{c}1.8508^{* * *} \\
(0.0857)\end{array}$ & $\begin{array}{c}1.8383 * * * \\
(0.0364)\end{array}$ & $\begin{array}{c}1.8399 * * * \\
(0.0364)\end{array}$ \\
\hline$R^{2}$ & 0.0822 & 0.0860 & 0.0885 \\
\hline$N$ & 26356 & 26356 & 26356 \\
\hline
\end{tabular}

Note: ${ }^{*}, *$, and ${ }^{* *}$ represent the significance levels $10 \%, 5 \%$, and $1 \%$, respectively.

In addition, the effect of the policy may have been affected by the investment of fiscal costs and the input of higher-level governments. In Table 5, the regression results in column (2) indicate the degree of government intervention in state-owned forest farms. It is significantly positive at the $10 \%$ level, indicating that the degree of government intervention can better promote the exertion of policy effects. 
The regression result in column (3) was significantly positive at the $1 \%$ level, which indicates that higher government investment costs lead to the better economic development of impoverished state-owned forest farms and that government financing can support the economic development of impoverished state-owned forest farms. However, it is not difficult to see that, although the Chinese government attached great importance to the development of state-owned forest farms and increased investment into financial and higher-level government costs, the estimated coefficient was still small.

\section{Discussion}

The results of the present study show that implementing the policy of establishing the list of impoverished state-owned forest farms has significantly promoted the economic development of impoverished state-owned forest farms. This result is similar to those reported by Sachs [11,20], Papyrakis [21], Pettersson [22], Menard [23], Koyuncu [24], Ting Zuo [42], Chao Cai [43] and Yaohui Zhao [44].

However, the effect of policy implementation will be limited by the conditions of the forest farm itself. Therefore, by formulating a series of poverty alleviation measures such as special poverty alleviation funds, infrastructure construction, and social security, we can ensure that the existing impoverished state-owned forest farms can get rid of poverty completely. In addition, the impact of human capital on poverty alleviation policies will significantly improve the economic benefits of forest farms, and it is necessary to increase direct subsidies to employees of impoverished state-owned forest farms. In terms of the forest resource base, the forest resources of impoverished forest farms are rich, and available reserve forest resources have great potential. However, the development and utilization rate of forest resources is low, and the potential of carrying out business activities is lower than that of state-owned forest farms. The reasons may be as follows: First, the number of state-owned impoverished forest farms is large, the average operating area is small, and the degree of fragmentation is high. It is difficult to form a scale of production and operation. Second, the protection and management of forest resources have lacked market-oriented management, which affected the effective allocation of forest resources. Finally, the condition of forest farm roads is an important factor restricting the economic development of forest farms. In the process of poverty alleviation of forest farms, road construction and investment in forest farms should continue to be valued so as to accumulate strength for the future development of impoverished state-owned forest farms.

It is worth noting that the Chinese government attached great importance to the development of state-owned forest farms and increased investment into financial and higher-level government costs, but the effect was still small, similar to the findings of Salaimartin [28], Fan Liming [45], and XU Chao [46], in which they found that government public policy does not reduce poverty. The possible reasons for this are as follows: First, the implementation of impoverished state-owned forest farms is affected by the effectiveness of intervention by the local government. As the development of state-owned forest farms relies entirely on the unified planning and management of local governments, factors such as the system's implementation environment and administrative barriers make it difficult for the effect of policy implementation to quickly show. Second, the influence of historical factors on state-owned forest farms. State-owned forest farms have both a large amount of funds due to redundant internal institutions and a historical financial accumulation of debts. Besides, the proportion of forest farm expenses relative to staff costs, social security, welfare, and other personnel expenses can be as high as $68 \%$. Fourth, impoverished state-owned forest farms lack long-term plans for capital use and do not pay attention to the use of funds and investment benefits. It is difficult to rely solely on the strength of the government to develop state-owned forest farms. Hence, the economic development of state-owned forest farms cannot completely depend on the degree of government intervention. While increasing the support of provincial fiscal funds, it is necessary to solve the cost of state-owned forest farm reforms as a whole, thereby reducing the gap with non-impoverished forest farms.

This study analyzed the performance impact of poverty reduction policies on impoverished state-owned forest farms, in terms of reducing poverty from a dynamic perspective, provides theoretical 
value and practical significance for precision poverty alleviation and stabilization in impoverished state-owned forest farms. However, this study has some limitations that should be noted. In the sample selection of this article, due to the wide distribution of state-owned forest farms in China, the differences in the experimental and control groups were very large, and the different results may have had certain deviations. In addition, existing studies have explored the impact of impoverished state-owned forest farms and poverty vulnerability in China but mainly relied on indicators to measure the poverty level of state-owned forest farms. In fact, the measurement of the poverty level of impoverished state-owned forest farms can effectively analyze the causes of poverty in such forest farms, but there has been no comprehensive and systematic analysis of the gap between impoverished and non-impoverished state-owned forest farms, which is a concern that will be addressed in subsequent research.

\section{Conclusions}

Based on the data from 4855 state-owned forest farms in 31 provinces in China from 2008 to 2017, this paper used the established list of inherently impoverished forest farms in 2013 as a "quasi-natural experiment". The research found that implementation of the policy significantly promoted the economic development of impoverished state-owned forest farms and caused the treatment group to increase by about $10.6 \%$ over the control group. This conclusion was verified by hypothesis testing and stability testing. Moreover, the establishment of a list of impoverished state-owned forest farms had an indirect impact on the economic performance of forest farms, through channels such as infrastructure poverty alleviation, human capital investment, and per capita income of forest farm employees. Then, the policy effect in non-impoverished counties was stronger than that in impoverished counties, and impoverished state-owned forest farms may not appear in impoverished counties. The financial cost input and higher-level government input (i.e., the degree of financial dependence on local governments) had a significant positive impact on the economic development of impoverished state-owned forest farms. Meanwhile, due to differences in economic foundations, factor endowment structures, and geographical and administrative characteristics, the policy effects on different forest farms were heterogeneous. For instance, forest farm personnel expenditures, forest farm resource status, and reserve forest land resource potential had a significant negative impact on poverty reduction in impoverished state-owned forest farms. The distance from the county seat had a significant impact on the policy effects of poverty reduction in impoverished state-owned forest farms. In the context of achieving the goal of complete poverty alleviation in impoverished state-owned forest farms, the poverty mechanisms of impoverished state-owned forest farms should be clarified.

Based on the development in China from 2008 to 2017, the mechanisms of poverty alleviation policies in impoverished state-owned forest farms were analyzed, and the following seven policy suggestions were put forward. First, relying on the rich natural resource advantages of state-owned forest farms, developing the forestry industry is a new mechanism to promote the economic structure adjustment of forest farms and reduce poverty in impoverished state-owned forest farms. Using the market as a guide, it is recommended to create a clustered ecological forestry industry gathering area, comprehensively utilize forest resources, develop an ecological forestry industry, and strengthen the construction of modern forest farms. Second, the government should increase financial costs and government investment in impoverished state-owned forest farms, improve the livelihoods and office conditions of forest farm employees, strengthen forest farm infrastructure construction, and increase employee satisfaction, in order to reduce the risk of impoverished state-owned forest farms returning to poverty. Third, although the state of forest resources and reserve forest land resources of state-owned forest farms cannot be committed to achieving a short-term increase in forest farm income, the corresponding supporting policies must be followed up at the same time to ensure that the poverty vulnerability of impoverished state-owned forest farms is reduced and the ecological functions of state-owned forest farms are brought into play. The vitality of state-owned forest farms must be improved to achieve sustainable growth. Fourth, the improvement in human capital quality of state-owned forest farm employees is an important driving force to solve the poverty of forest farms. 
Impoverished forest farms have an unreasonable staffing distribution, with a low proportion of work and skilled positions and a low proportion of low-skilled general management and maintenance staff, which has led to the problem of staff surplus and increased forestation costs. Therefore, state-owned impoverished forest farms should pay attention to the cultivation of the difference in the value of human capital in order to improve human capital quality, attract outstanding talent and young people to forest farm construction, and reduce the gap between impoverished and non-impoverished forest farms to achieve sustainable and healthy state-owned forest farm development. That is, the state should provide policy support to encourage state-owned forest farms to develop ecological forestry industries and products. In particular, impoverished state-owned forest farms located in impoverished counties should pay more attention to policy preferences.

Author Contributions: R.C. performed calculations, analyzed the data and edited the paper. M.H. and W.C. revised the manuscript and the coherence of the paper during the whole writing process. W.H. solidified the argument and language modification. All authors contributed to the drafting of the article and All authors have read and agreed to the published version of the manuscript.

Funding: This research was supported by the National Natural Science Foundation of China (Grant No: 71573018).

Conflicts of Interest: The authors declare no conflict of interest.

\section{References}

1. FAO (Food and Agriculture Organization of the United Nations). Available online: http://www.fao.org/ forest-resources-assessment/en/ (accessed on 7 September 2017).

2. Global Forest Resources Assessment 2020. Available online: http://www.fao.org/forest-resources-assessment/ en/ (accessed on 12 June 2017).

3. UNFCCC (United Nations Framework Convention on Climate Change). The Paris Agreement. Available online: http://www.unfccc.int/paris_agreement/items/9485.php (accessed on 5 October 2017).

4. Zanh, G.G.; Kpangui, K.B.; Barima, Y.S.S.; Bogaert, J. Migration and Agricultural Practices in the Peripheral Areas of Côte d'Ivoire State-Owned Forests. Sustainability 2019, 11, 6378.

5. Trædal, L.T.; Vedeld, P.O. Livelihoods and Land Uses in Environmental Policy Approaches: The Case of PES and REDD+ in the Lam Dong Province of Vietnam. Forests 2017, 8, 39. [CrossRef]

6. NDRC (National Development and Reform Commission). Enhanced Actions on Climate Change: China's Intended Nationally Determined Contributions. Available online: http://www.gov.cn/xinwen/2015-06/30/ content_2887330.htm (accessed on 30 June 2015).

7. Liu, Y.; Li, Y. Revitalize the world's countryside. Nature 2017, 548, 275-277. [CrossRef] [PubMed]

8. Huang, Z. On the Strategy of Rural Revitalization in China. Chin. Rural Econ. 2018, 4, 2-12. (In Chinese)

9. National Forestry and Grassland Administration. 4612 state-owned forest farms have basically completed the task of reform. Available online: http://env.people.com.cn/n1/2019/0110/c1010-30515631.html (accessed on 10 January 2019).

10. National Forestry and Grassland Administration. The Indicators and Defining Method of the Poverty State-Owned Forest Farms (LY/T2088-2013); China Stand. Pres: Beijing, China, 2013; pp. 1-8.

11. NDRC (National Development and Reform Commission). State-owned forest farm reform plan. Available online: http://www.gov.cn/gongbao/content/2015/content_2838162.htm (accessed on 17 March 2019).

12. Pasquale, T. Growth, Lnequality and Poverty in Emerging and Transition Economics. Transit Study Rev. 2010, 16, 979-1001.

13. Sachs, J.D.; Warner, A.M. The Big Rush, Natural Resource Booms and Growth. J. Dev. Econ. 1999, 59, 43-76. [CrossRef]

14. Corden, W.M.; Neary, J.P. Booming Sector and De-industrialization in a Small Open Economy. Econ. J. 1982, 92, 825-848. [CrossRef]

15. Matsuyama, K. Agriculture Productive, comparative advantage, and Economic Growth. J. Econ. Theory 1992, 58, 317-334. [CrossRef]

16. Ross, M.L. The Political Economy of the Resource Curse. Camb. Univ. Press. 1999, 1, 297-322. [CrossRef]

17. Cheng, M.; Jin, Y.; Shi, Q. Focusing on Education or Health Improvement for Anti-poverty in Rural China: Evidence from National Household Panel Date. Econ. Res. J. 2014, 49, 130-144. (In Chinese) 
18. Zhang, W.; Wang, S. Poverty Alleviation Policy, Income Distribution and Poverty Reduction in Rural China. Issues Agric. Econ. 2013, 34, 66-75+111. (In Chinese)

19. Luo, C. Economic Growth, Inequality and Poverty in Rural China. Econ. Res. J. 2012, 47, 15-27. (In Chinese)

20. Sachs, J.; Warner, A.M. Natural Resources and Economic Development: The Curse of Natural Resources. Eur. Econ. Rev. 2001, 45, 827-838. [CrossRef]

21. Papyrakis, E.; Gerlagh, R. The Resource Curse Hypothesis and Its Transmission Channels. J. Comp. Econ. 2004, 32, 181-193. [CrossRef]

22. Boschini, A.; Pettersson, J.; Roine, J. The Resource Curse and its Potential Reversal. World Dev. 2013, 43, 19-41. [CrossRef]

23. Menard, C.; Shirley, M.M. Handbook of New Institutional Economics; Springer: New York, NY, USA, 2005; pp. 230-568.

24. Koyuncu, C.; Yilmaz, R. Impact of private forest ownership on deforestation and poverty. Qual. Quant. 2013, $47,1657-1664$.

25. Holden, S.; Benin, S.; Shiferaw, B.; Pender, J. Tree planting for poverty reduction in less-favored areas of the Ethiopian highlands Small-scale Forest Economics. Manag. Policy 2013, 1, 63-80.

26. Rosengren, L. Planted Forests and Trees Can Restore Landscapes and Alleviate Poverty. World For. 2012, 16, 443-463.

27. Murshed, S.M. When Do Natural Resource Abundance Lead to a Resource Curse. Discuss. Papers 2004, 4, $1-54$.

28. Sala-i-Martin, X.; Subramanian, A. Addressing the Natural Resource Curse: An Illustration from Nigeria. J. Afr. Econ. 2013, 22, 570-615. [CrossRef]

29. Toth, D. Development and Forecast of Employment in Forestry in the Czech Republic. Sustainability 2019, 11, 6901. [CrossRef]

30. Wang, M.; Chen, W. Study on the Development Level of County's State-Owned Forest Farms: Taking Hebei Province as an Example. Issues For. Econ. 2017, 7, 35-40+102. (In Chinese)

31. Zhang, W.; Kaiyue, M.A.; Jin, L. Poverty identification and poverty reduction strategy based on multidimensional poverty measurement. J. Arid Land Resour. Environ. 2019, 12, 22-27. (In Chinese)

32. Li, Y.; Liu, J.-C.; Chen, W.-H. Life Satisfaction and Influencing Factors of Chinese State-owned Forest Farm Workers. Northwest. Popul. J. 2014, 35, 124-128. (In Chinese)

33. Qiao, Y.; Chen, W.; Zeng, Q. Evaluation on the Effectiveness of State-owned Forest Farm Reform: Statistical Analysis of Employees' Sense of Gain. Issues For. Econ. 2019, 39, 62-70. (In Chinese)

34. Rong, C. Study on the benefits of woodland under different management conditions. Issues Agric. Econ. 1997, 7, 1-5. (In Chinese)

35. Liu, C.; Zhang, Y.; Liu, H. The Difficulties and Policy Implications for the Reform of the State-owned Forest Farms. For. Econ. 2019, 417, 10-15. (In Chinese)

36. Liu, J.L.; Xu, T. Research on the Changes of Forest Rights based on the Bundles of Associated with Positions-A Case Study of Pingquan County in Hebei Province. Hebei Acad. J. 2016, 36, 124-129. (In Chinese)

37. Yi, A.; Liu, J. Study on poverty standard of state-owned forest farm. Inner Mongolia Soc. Sci. 2010, 31, 110-114. (In Chinese)

38. Guo, J.; Wu, G. Multidimensional Poverty Measurement Based on Different Indicators and Weight Selection: A Case Study of Poverty Counties in Shanxi Province. Chin. Rural Econ. 2015, 2, 12-20. (In Chinese)

39. Bai, X.; Yu, T.; Yan, G. An Overview of Forest Tenure System Reform in Foreign Countries. World For. Res. 2017, 30, 1-7. (In Chinese)

40. Bertrand, M.E.; Duflo, S.M. How Much Should We Trust Differences -in -Differences Estimates? Quart. J. Econ. 2004, 119, 249-275. [CrossRef]

41. Heckman, J.J.; Ichimura, H.; Todd, P.E. Matching as an Econometric Evaluation Estimator: Evidence from Evaluating a Job Training Programmed. Rev. Econ. Stud. 1997, 64, 605-654. [CrossRef]

42. Ting, Z.; Kuang, Z. Vulnerability of Poor Farmers and Risk Mitigation of Microfinance. J. Rural Econ. 2007, 12, 52-56. (In Chinese)

43. Li, L.; Chao, C. Research on the Supply of Rural Public Goods from the Perspective of Poverty Vulnerability. Pub. Fin. Res. 2014, 1, 25-28. (In Chinese)

44. Zhang, C.; Giles, J.; Zhao, Y. Polly Evaluation of China's New Rural, Pension Program: Income, Poverty, Expedition, Subjective Wellbeing and labor Supply. China Econ. Quart. 2015, 14, 203-230. (In Chinese) 
45. Fan, L.; Xie, E. Does public transfer reduce vulnerability? Econ. Res. J 2014, 8, 67-78. (In Chinese)

46. Xu, C.; Li, L. Does Urban and Rural Subsistence Security System Reduce Future Poverty? Empirical Analysis Based on Vulnerability of Poverty. Fin. Trade Econ. 2017, 5, 5-19+146. (In Chinese)

(C) 2020 by the authors. Licensee MDPI, Basel, Switzerland. This article is an open access article distributed under the terms and conditions of the Creative Commons Attribution (CC BY) license (http://creativecommons.org/licenses/by/4.0/). 